\title{
E-TUTORSHIPS AND E-LEARNING - RE-SKILLING LIBRARIANS FOR INTERACTIVE COMMUNICATION IN VIRTUAL ENVIRONMENTS
}

\author{
Valentina Elvira Comba \\ Director, e-Learning Centre, University of Bologna, \\ valentina.comba@unibo.it
}

\begin{abstract}
In university, research, and health institutions the need has become evident for high quality information literacy instruction in order to develop and support research, teaching and other services. The University of Bologna launched an Information Literacy Project in 2003 to improve information skills at all levels. Librarians were involved in a course of "training for trainers" and in the production of learning objects/tutorials for students and teachers. This experience was an interesting approach not only to a virtual environment, but also to the basics of pedagogical requirements for a good training course.

As a second example of this re-skilling effort, the experience of a course delivered in 2008 for hospital librarians as e-tutors on the Moodle platform is also be presented. The critical aspects of this initiative within traditional Italian universities will be highlighted: the transition to a digital library-oriented profession is made difficult by national and local norms and behaviours. Moreover, technical aspects regarding barriers of access to e-learning content in a hospital/university context will be analysed. It has been a real struggle to develop new professional attitudes based on effective communication skills.
\end{abstract}

\section{INTRODUCTION}

This paper analyses a specific area of new knowledge and innovative skills for librarians, and two experiences of promoting this change. Digital information, electronic resources, and virtual learning environments are the context in which academic/research/special librarians are working today. It is more and more difficult to meet users just by waiting for them inside a library. Moreover, information resources, despite an apparent ease of availability, are becoming very complex, widespread, and varied in quality. The need for support, expert searching, and information literacy teaching is felt to be essential. Thus the librarians' teaching role must be supported and enhanced. In many countries, and in a variety of contexts, learning and teaching information literacy has been developed within a virtual learning environment with the use of e-learning platforms and wikis, blogs and other features of Web 2.0. But for effective teaching it is not sufficient to have 
technical knowledge of these instruments: a pedagogical background and training as trainers have proved to be essential.

Many similar experiences have been undertaken over the past years. The path followed in our case takes into account other countries' experiences; besides successes and improvements, critical aspects and difficulties are also presented. It may be that these difficulties would not be peculiarly Italian, and therefore a discussion of these circumstances can suggest innovative solutions.

\section{E-LEARNING AND LIBRARIES}

Since the late 1990s, a large number of articles and books have shown the interesting connections between e-learning and the role of libraries. On one hand, the focus has been on the role of libraries and librarians' skills in the management of digital teaching objects, from providing metadata to managing digital repositories. The most prominent aspect of this area has been the role of libraries in embedding electronic resources in learning objects. ${ }^{1}$ On the other hand, librarians started to use broadcasting and television and later e-learning to teach information literacy and other subjects to library users. At a 1997 conference, the author first learned about the use of computers in distance education. ${ }^{2}$

One of the first international meetings devoted to this aspect was "e-Learning for Management and Marketing in Libraries" held in Geneva in 2003. In the keynote speech, John Ellison pointed out the critical aspects for a teacher providing distance learning:

Is is strongly recommended that professors gain experience by developing and teaching distance learning courses before attempting to develop a complete degree program. Time is such a critical factor when developing distance learning courses that the thought of committing to a complete degree program initially without first experiencing the hours and energy required to develop and teach one course is overwhelming. Any professor can conceptualize a complete library and information degree program on paper in a matter of minutes. But it is something else to be able to offer and deliver such a program with any degree of success without first experiencing the time and energy required to teach distance learning courses. ${ }^{3}$ (p19)

Other contributions within the same meeting highlighted social and technical problems; various distance learning methods and media were discussed. ${ }^{4}$

The Sixth World Conference on Continuing Professional Development and Workplace Learning for the Library and Information Professions in Oslo in 2005 included many contributions that highlighted the importance of e-learning in the profession, and in particular for the delivery of information literacy courses. ${ }^{5}$ More recently, the IFLA Education and Training Section established an E-Learning Dis- 
cussion Group, which held sessions at the conferences in Durban and Quebec. In those sessions many experiences were presented about this subject.

\section{DEVELOPING TEACHING ROLES}

There has been a growing awareness of e-learning as a powerful tool for improving information literacy teaching and, in general, communication with users. Mei$\mathrm{Yu}$ Wang and Ming-Jiu Hwang ${ }^{6}$ in their paper about "the e-learning library" refer to the most important learning styles and theories, with particular emphasis on behaviourism and constructivism:

Meanwhile, since maturing Internet technologies are capable of providing an unparalleled technological foundation for designing innovative interactions that are highly engaging, communicative and participative, to formally render models of discourse into cognitive tools supporting effective educational dialogue ... These approaches are also addressing the need for the e-learning library to implement theoretically founded interaction models and designs that incorporate learning theories. ${ }^{6(\mathrm{p} 412)}$

Therefore librarians have begun to understand not only the need to manage elearning platforms and produce learning objects for users' self-instruction, but also to explore the basics of pedagogy and teaching skills.

An American survey of mainly public libraries, Trends in E-Learning for Library Staff, ${ }^{7}$ shows that by 2006 there was growing interest in e-learning, but that there was a perception by library staff of significant barriers of costs, staff time, and lack of expertise.

A few years later in England, the involvement in e-learning was one of the highest ranked professional skills in the JISC Attitudinal Survey, an annual survey conducted on at the University of Kent. It showed "that senior academic librarians believe that managing and promoting e-resources and e-content will be their main challenges over the next few years." 8

Among the key findings, the report says:

Head/senior learning and librarian staff from UK institutions feel best informed about e-Learning/VLEs and subjects relating to the library and content management and storage, and least informed about network capabilities, eResearch/e-Science and Green computing/ICT... The highest awareness of JISC funded activity is in the areas of access management and e-Learning/VLEs. Since 2007, there have been significant increases in the proportions of institutions aware of JISC funding activity in access management, open access and social software/Web 2.0. ${ }^{8}$ (p6) 
It is because of this growing awareness of e-learning in the field that we thought that it would be of interest to present the experiences that we have led in the past years.

\section{THE BOLOGNA UNIVERSITY EXPERIENCE}

In 2001 the University of Bologna started a large Digital Library Project, "AlmaDL." In the second phase of the project, it was proposed to use part of the budget to for two related sub-projects: one aimed to develop a digital reference service and the other information literacy teaching. These proposals were inspired by a report that defined the scenario, the social aspects, and the new leading roles of librarians in the digital library era: Wendy Pradt Lougee's Diffuse libraries: emergent roles for research libraries in the digital age. ${ }^{9}$

About information literacy she says:

What has changed in the learning environment?...First, technologies emerged that enabled distance-independent, asynchronous venues for instruction. These technologies were adopted not only for use in distance education programs but also for more generalized applications on campus. The second phenomenon was the growing pressure to rethink the academy's approaches to teaching and learning, particularly with respect to the undergraduate community. These two forces have created a volatile environment, but one that offers tremendous opportunities for libraries.... How do these changing values and priorities in the educational experience affect the library and its roles in support of teaching and learning? Do traditional approaches of bibliographic instruction still resonate? While information sources and methods for finding information are still a useful component of library instruction, a broader construct of information literacy has emerged as a framework for effective information inquiry. This framework can provide a repertoire of essential skills that support students in new learning contexts.

What skills are necessary for information inquiry in the digital age? Is it possible to separate content skills from the tools that facilitate access? Has the basic function of inquiry changed as new analytic capabilities become available? A number of perspectives have been brought to bear in understanding these new dimensions of learning and associated skills. ${ }^{9}$ (p20)

The information literacy teaching sub-project funded two important initiatives. The first was a course on "Training for Trainers." This course, taught by a consultant who has credentials in pedagogy and in psychology, and is an expert trainer, involved 64 librarians (out of 307 employed at the University of Bologna 2003). The course was for forty hours and repeated five times). A follow-up after one year reviewed the results in practice. The content of the course included:

- Basics of the communication theory 
- Listening and communication techniques

- Learning styles and strategies

- Basics of teaching: course planning and management

- Learning and the group: learning agreement; expectation and motivation; question management; dealing with conflicts; group dynamics.

The training also included project work and a real course developed by the participants and presented by them to the teacher/consultant.

The report based on the questionnaire at the end of the course shows the following results:

- $59.52 \%$ of participants agree on the high coherence of course objectives and content

- $52.38 \%$ of participants consider the course useful

- $38.10 \%$ of participants consider the content difficult to implement at University level.

The follow-up seminar reviewed the initiatives developed after the course. Most librarians reported frustration, after a strong expectation of success and reward by the academic bodies and the students. Nearly all participants agreed with the fact that their students were not attracted to a course without credit "rewards;" but the only person entitled to assign credits in the current regulations of Italian universities is the professor or teacher of an official course. Therefore an agreement with a professor to assign credits to the attending students had to be made. This path has been followed in recent years with good results.

The second initiative has been the production of learning objects for basic information literacy (CIL modules) that can be attended by users in two forms: 1) in self instruction mode ${ }^{10}$ or on the ATutor e-learning platform. ${ }^{11}$ These two modes allow librarians to use the tutorials inside their information literacy programs or to recommend that students read and follow the modules before starting their research. There is also an English version of the tutorial for the foreign students. ${ }^{12}$

A short course was offered to encourage librarians to use the ATutor platform. But, in this context, the priority was to develop as many face-to-face courses as possible, so as to promote the use of electronic resources and complex searches. This choice is due to the wide variety of disciplinary content taught. Subject librarians and database experts may propose seminars on different subjects or approach and freely refer to the basic methodology or searching offered by the three online tutorials.

Presently, the University of Bologna Libraries' Information Literacy website lists more than forty courses and seminars addressed to students and special user groups. ${ }^{13}$ In many cases a professor sponsors the courses/seminars, and assigns credits to the successful students.

In the short term, the tutorials will be moved into the Moodle platform, managed by the University of Bologna E-Learning Centre. This change will give the librari- 
ans the opportunity for a re-training course about the more complex e-learning environment. We hope that the course will give us the chance for a re-appraisal of the librarians' experience.

In general, librarians appreciated the "Training for Trainers" initiative; they saw the opportunity not only to renovate the old style "guide for library users" but also to enhance the utilization of electronic resources. Re-skilling has been felt as personally rewarding, but not sufficiently recognized by the Faculties. In fact, in Italian universities there are impassable barriers between "teachers" and "nonteachers," and any attempt by librarians to train users may be seen as menacing professors' privileges.

\section{THE INFORMATION LITERACY FOR BIOMEDICINE E-TUTORS COURSE}

This course developed in a different context but was inspired by the same aims and objectives as the University of Bologna experience.

In 2004 the Emilia Romagna Region Health Authority financed a regional project called "ILB: information literacy in campo biomedico". The main objectives of this project were: 1) survey the perceived gaps in medical doctors' information searching skills; 2) identify the most essentials sources, databases and search engines for hospital medical personnel among the ones available in the regional hospitals; 3 ) produce and deliver a blended learning course, taught by hospital librarians, to fill these gaps and expand hospital medical personnel information skills.

The third objective created a unique opportunity to develop a course for the hospital librarians about their new role of e-tutors.

In this case it is reductive to describe the aim of the course as supplying librarians with the general information about the e-learning platform. The content of the course, held in the Spring 2008, included:

- Overview of new roles for hospital librarians as trainers in virtual learning environments

- Basics about learning agreement, course planning and management

- Overview and practice of some Moodle collaborative tools: forum, calendar, homework; overview of the reports tools and other useful features

- Learning objects content evaluation

- Case studies exercises (i.e. examples of search paths for medical subject questions; medical doctors' skills assessment).

Most of the twenty-three hospital librarian participants have had experience as trainers for hospital staff (medical doctors, specialists, nurses and other health staff), especially in the areas of evidence-based medicine and evidence-based nursing. They normally teach more than three courses a year and spend quite a large part of their time performing expert online searches, such as systematic re- 
views. Therefore the learning objects were perceived as a tool (nota) to present basic concepts to their trainees and a means of earning individual time and space for single questions, which it is not always easy in a classroom situation.

As an introduction, an overall analysis of the medical librarian's new roles was presented. Particular reference was made to the Medical Library Association US (MLA) descriptions of professional requirements:

Teaching ways to access, organize, and use information to solve problems is an essential and ever-widening responsibility of the health sciences librarian. Effective instruction entails not only knowledge of the structure and content of specific courses and technology but also an understanding of and expertise in

- learning theory and cognitive psychology,

- curriculum and instructional development,

- instructional systems design,

- educational needs assessment and analysis,

- learning style appraisal,

- instructional methodologies, and

- evaluation of learning outcomes. ${ }^{14}$

The course was organized in two face-to-face sessions of five hours each, and almost ten hours of online homework. A questionnaire and assignments were distributed and the work of each participant was monitored.

It was the first time that these librarians worked in a virtual learning environment, and the course itself, delivered through the Moodle platform, led them to consider the advantages and the problems of being "virtual trainees." In light of this lack of experience, more time was spent letting them explore and test the Moodle platform tools and features than assessing their ability to support a user in performing a good search, for example in EMBASE.

As a matter of fact, the course was quite successful from the point of view of the teacher-participant interaction and the case studies; but some technical problems occurred involving platform access by some participants located inside a hospital or a local health authority. Access to the platform and to the learning objects was the main problem encountered. Italian hospitals' information systems normally install powerful firewalls that protect health data and patient privacy. Moreover, personal computers are protected and cannot easily access external resources such as e-learning platforms nor use certain types of software. Therefore the hospital librarians had problems accessing the learning objects managed inside the Moodle platform of the Modena and Reggio University E-Learning Centre (CEA). Some personal computers also had no audio on board and headsets were not provided. Nevertheless, the short course was successfully completed, but hospital librarians asked for a refresher course in proximity with the delivery of the ILB e-learning course.

At the moment, the Santa Maria Nuova Hospital - the main provider of the course - is still not able to deliver it because of technical problems. For example, 
the Flash ${ }^{\circledR}$ version installed by the hospital is not the same as that used in the ecourse. We are looking forward to delivering the training in alternative locations to overcome the firewall and technical protections problems.

\section{LESSONS LEARNED}

In the different environments described, a great openness of mind and a true wish to learn new skills were found among librarians. The professionals' overall age was over thirty, but in general everybody was ready to learn new skills.

The main factors delaying the full development of information literacy programs and e-tutorship are the following:

- regulations and social conditions that prevent universities and other institutions from allowing librarians to deliver officially recognized training courses

- stereotypes and staff organization trends that prevent librarians from dedicating themselves to teaching and creating training courses

The technical aspects discussed in relation to the hospitals are problems for all elearning courses, so cannot be considered as an obstacle for these particular objectives.

\section{CONCLUSIONS}

In these experiences we learnt the importance of pedagogical and methodological issues coupled with technological innovation, such as those encountered in using e-learning platforms. The need is clear for awareness of the difference between face-to-face and online communication. Thus the clear statement of objectives, the learning path, and the learning agreements are essential elements to establish the relationship with trainees.

Re-skilling librarians to take on the roles of e-tutor does not imply only learning to be at ease in a virtual learning environment; it also requires librarians to assume the role and tasks of a mindful teacher.

\section{ACKNOWLEDGEMENTS}

Thanks to Alina Renditiso and Laura Bertazzoni for helping me to recollect data about the "Training for Trainers" course. I am also very grateful to Maureen Lister for revising and editing my English text. 


\section{RFEFERENCES}

1. OCLC E-Learning Task Force. Libraries and the enhancement of e-learning. October 2003. http://www5.oclc.org/downloads/community/elearning.pdf (accessed 31 Jan 2009).

2. Leadership Roles for Librarians in the New Learning and Information Environments: Advancing the Educational Perspective of Health Sciences Librarians. Medical Library Association post-conference symposium; 1997 May 29 May; Seattle.

3. Ellison JW. Critical issues related to Internet teaching. In: McAdam D, editor. e-learning for management and marketing in libraries $=e$-Formation pour le marketing et le management des bibliothèques. Papers presented at the IFLA Satellite Meeting, Management and Marketing Section; 2003 July 28-30 ; Geneva, Switzerland. Munich: KG Saur, 2005. p18-37.

4. Diarra M. La formation à distance dans un context sud-sud: défis et enjeux. In: McAdam $\mathrm{D}$, editor. e-learning for management and marketing in libraries $=e$ Formation pour le marketing et le management des bibliothèques. Papers presented at the IFLA Satellite Meeting, Management and Marketing Section; 2003 July 28-30; Geneva, Switzerland. Munich: KG Saur, 2005. p99-114.

5. Genoni P, Walton G, editors. Continuing professional development-preparing for new roles in libraries: a voyage of discovery. Sixth World Conference on Continuing Professional Development and Workplace Learning for the Library and Information Professions; 2005 Aug 10-13; Oslo. Munich: KG Saur, 2005.

6. Wang MY, Hwang MJ. The e-learning library: only a warehouse of learning resources? The Electronic Library 2004;22:408-415.

7. OCLC. Trends in e-learning for library staff: a summary of research findings. 2006. www.webjunction.org/learningcenter (accessed 22 Jan 2009).

8. JISC Monitoring Unit, University of Kent. JISC attitudinal survey. 2008: head and senior learning and librarian staff. http://www.jisc.ac.uk/publications/ publications/attitudinalsurvey2008librariansreport.aspx (accessed 31 Jan 2009).

9. Lougee WP. Diffuse libraries: emergent roles for the research library in the digital age. Washington DC: Council on Library Resources, 2002. http:// www.clir.org/pubs/reports/pub108/contents.html (accessed 31 Jan 2009).

10. University of Bologna. CIL - Corso di information literacy. http://www.sba. unibo.it/portale/formazione/corso-di-information-literacy (accessed 31Jan 2009).

11. ATutor e-learning platform. http://ilit.cib.unibo.it/ATutor/login.php (accessed 31 Jan 2009).

12. University of Bologna. Information literacy-basic course. http://www.sba. unibo.it/portale/formazione/corso-di-information-literacy/cil/cilmultimediale_old/eng/default.htm (accessed 31 Jan 2009). 
13. University of Bologna. Archivio delle iniziative di formazione. http://www. sba.unibo.it/portale/formazione/iniziative/archivio-delle-iniziative-di-formazione (accessed 31 Jan 2009).

14. Competencies for lifelong learning and professional success: the educational policy statement of the Medical Library Association. http://www.mlanet.org/ education/policy/knowledge.html (accessed 31 Jan 2009). 